\title{
THE APPLICATION OF ENZYMES FOR THE REMOVAL OF DYES FROM TEXTILE EFFLUENTS
}

\author{
Kiro D. Mojsov ${ }^{1 *}$, Darko Andronikov ${ }^{1}$, Aco Janevski $^{1}$, Aco Kuzelov ${ }^{2}$, Stevan Gaber ${ }^{3}$
}

(PROFESSIONAL PAPER)

UDC 628.31:677:577.15

${ }^{1}$ Faculty of Technology, University “Goce Delčev” Štip, Republic of Macedonia
2 Faculty of Agriculture, University “Goce Delčev” Štip, Republic of Macedonia
${ }^{3}$ Faculty of Economics, University “Goce Delčev" Štip, Republic of Macedonia

Dwindling water resources is a global problem. The effective effluent treatment is an important step towards conserving our water resources. Some pollutants such as dyestuffs resist degradation by conventional treatment methods and persist in the environment. Dye wastes represent one of the most problematic groups of pollutants because they can be easily identified by the human eye and are not easily biodegradable. The use of biotechnological processes in textile dye effluents treatment has attracted considerable attention and achieved interesting results in recent years. This work describes the use of enzymes as an alternative method for the treatment of such pollutants. Noteworthy processes for the treatment of dye waste include a biological treatment, filtration, catalytic oxidation, a sorption process and the combination of treatments. This emphasizes the need for current and future research with the focus on developing economically feasible and environmentally sustainable wastewater treatment practices.
Keywords: enzymes, dyes waste, textile effluents, treatment methods

\section{Introduction}

The limited availability of fresh water is a global crisis. The growing consumption of fresh water by anthropogenic activities has taken its toll on available water resources. Unfortunately, water bodies are still used as sinks for wastewater from domestic and industrial sources. During the process, textile industries release large quantities of intensely colored and hazardous effluents which cause serious environmental pollution. Dyeing, desizing and scouring are the major sources of water pollution in textile effluent. Textile and dyestuffs waste waters are characterized by their highly visible color, high COD (Chemical Oxygen Demand), suspended solids and alkaline $\mathrm{pH}(9-11)$ [1] thus effluent discharge from these industries into the environment is a major cause for concern. Specific problems pertaining to the textile industry include color removal from dyehouse effluent and toxic heavy metal compounds. Currently, much research is being carried out to resolve these problems and biotechnology would appear to offer the most effective solutions. Several chemical and physical decolorization methods (adsorption, precipitation, flocculation, oxidation, electrolysis and membrane extraction) are effective for the color removal but use more energy and chemicals than biological processes [2,3].

Synthetic dyes are preferred for use over natural dyes due to their superior performance. Also, synthetic dyes offer a wider variety of colors. Wastewater or effluents from industries that manufacture paints, pigments and color cosmetics contain a variety of synthetic dyes. Furthermore, the effluents from textile industries contain a variety of other compounds, such as dispersing agents, salts, emulsifiers and organometallic compounds containing heavy metals. However, in recent times, the need to replenish our water resources has been receiving increasing attention. This has led to the development of strategies to return water to its source in the least toxic form possible, to enable reutilisation of water.

New technologies must be developed and adapted to achieve such low limits of effluent discharge toxicity. Enzymes of the oxidase type, particularly laccases are now used as an alternative to the conventional effluent treatments. Although the growing impact of environmental protection on industrial development promotes ecofriendly technologies, reduced consumption of water and lower output of wastewater, the discharge of effluents with synthetic dyes is very problematic. Due to their stability under sunlight and resistance to microbial attack, the majority of dyes are not degraded by conventional treatments. The research of powerful and practical treatments to decolorize and degrade dyeing wastewater to decrease their environmental impact has attracted an increasing interest.

Traditional physico-chemical treatments applied to the purification of dyeing wastewaters include, among

\footnotetext{
*Author address: Kiro D. Mojsov, Faculty of Technology, University "Goce Delčev" Štip, Krste Misirkov No. 10-A, P.O.Box 201, 2000 Štip, Republic of Macedonia

E-mail: kiro.mojsov@ugd.edu.mk

The manuscript received: January, 12, 2016.

Paper accepted: February, 25, 2016.
} 
others, adsorption with inorganic and organic supports, coagulation, filtration, ion exchange. These procedures lead to effective decolorization, but their application is restricted due to some problems such as the formation of sludge. Biological decolorization (aerobic and anaerobic type) is the most common and wide spread technique used in the textile effluent treatment [4]. These methods include biosorption, use of enzymes, aerobic and anaerobic treatments etc. [5]. Only biotechnological solutions can offer complete destruction of the dyestuff, with a co-reduction in BOD (Biochemical Oxygen Demand) and COD. The application of microorganisms to the biodegradation of synthetic dyes has been an attractive alternative. A series of aerobic and anaerobic biological methods, including activated sludge, mixed cultures, fungi, bacteria or algae have been studied for the dyes degradation. However, due to chemical stability and resistance to microbial attack of several dyes, many of these methods are not effective.

The textile wastewater treatment with enzymes from fungi can be simpler and more efficient than the traditional treatments. The enzymes are highly selective and can effectively treat the wastes. The textile industry includes a wide range of activities, from the preparation of raw material to pre-treatment, dyeing and finishing of textile material. All these activities consume water and energy and are highly polluting [6]. Due to the wide variety of fibers, dyes, process auxiliaries and final products, these processes generate waters of great diversity and chemical complexity. This complex composition is reflected in the color, in a high ratio between chemical oxygen demand and biochemical oxygen demand (COD/BOD5) in the presence of suspended matter and, possibly, heavy metals, and in variable $\mathrm{pH}$ values, mostly in the alkaline range [7]. Despite the high volume of waste and its high organic load, the main problem of textile industry effluents is related to the color generated by unfixed dyes during textile processing and directly released to the effluent. These factors upset the ecological balance of the receiving water body. Thus, the presence of synthetic dyes is a serious environmental concern. Evidently, it is necessary to remove colorants from the effluent before it is discharged into a water body.

Textile industry effluents

Textile industries consume large volumes of water and chemicals during wet processing of textiles. Slashing, bleaching, mercerizing and dyeing are major consumption activities, as well as waste water generation. The chemical reagents used during the manufacture and processing are diverse in the chemical composition ranging from inorganic compounds to polymers and organic products. The major pollutant types identified in textile wastewater are summarised in Table 1 along with their main origin in the textile manufacturing processes.
Table 1. Effluent characteristics from textile Industry

\begin{tabular}{|c|c|c|}
\hline Main processes & Major chemical types & Pollutants \\
\hline Sizing & Starch, waxes, carboxymethyl cellulose & High in BOD, COD \\
\hline Desizing & $\begin{array}{l}\text { Starch, carboxymethyl cellulose, fats, waxes, } \\
\text { pectins }\end{array}$ & $\begin{array}{l}\text { Sodium hydroxide, } \\
\text { cotton wax }\end{array}$ \\
\hline $\begin{array}{l}\text { Desizing, Scouring, } \\
\text { Washing, Dyeing }\end{array}$ & $\begin{array}{l}\text { Starches, enzymes, fats, greases, waxes, } \\
\text { surfactants, acetic acid }\end{array}$ & Organic load \\
\hline Dyeing, Scouring & Dyes, scoured wool impurities & Color \\
\hline Dyeing & Ammonium salts, urea, phosphate & Nutrients $(N, P)$ \\
\hline $\begin{array}{l}\text { Scouring, Desizing, } \\
\text { Bleaching, Mercerizing, } \\
\text { Dyeing, Neutralization }\end{array}$ & $\begin{array}{l}\mathrm{NaOH} \text {, mineral/organic acids, sodium chloride, } \\
\text { silicate, sulphate, carbonate }\end{array}$ & Acids, Alcalis and salts \\
\hline Dyeing & $\begin{array}{l}\text { Sulphate, sulphite and hydrosulphite salts, } \\
\text { sulphuric acid }\end{array}$ & Sulphur \\
\hline $\begin{array}{l}\text { Desizing, Bleaching, } \\
\text { Dyeing, Finishing }\end{array}$ & $\begin{array}{l}\text { Heavy metals, reducing agents, oxidising } \\
\text { agents, biocides, quaternary ammonium salts }\end{array}$ & Toxic compounds \\
\hline
\end{tabular}

Dyes

From the very beginning, people have demonstrated the need to add color to all that surrounds them. They use dyes of natural origins such as soot, manganese oxide, hematite and ochre for painting their stories in caves, their skins and their clothes. Textile natural dyes were mainly obtained from plants, insects, fungi and lichens. Mauveine, the first synthetic dye, was discovered in 1856 by William Henry Perkin. Since then, thousands of new synthetic dyes have been produced. Nowadays, the total annual world textile dye production is estimated at about $7 \times 10^{5}$ tons, with more than 100,000 dyes available on the market [8]. The largest consumer of these dyes is the textile industry.

Dyes may be classified according to either chemical structure (chemical classification) or by usage (coloristic classification) [9]. Chemical classification is predominantly used by dye chemists who use terms such as azo dyes, anthraquinone dyes, or phthalocyanine dyes. On the other hand, the dye technologist uses coloristic classification and speaks of "reactive dyes for cotton" and "disperses dyes for polyester" [9].

Dyes can be divided in 20-30 different groups regarding their chromophores. The most important are azo (monoazo, diazo, triazo, polyazo), anthraquinone, phthalocyanine and triarylmethane dyes. Azo dyes represent about $70 \%$ on the weight basis of the total annual world production [10].

Color is the first contaminant to be recognized in wastewater. The presence of very small amounts of dyes in water (less than 1 ppm for some dyes) is highly visible and affects not only the aesthetic aspect and water transparency, but also the absorption and reflection of sunlight, interfering with aquatic life in lakes, rivers and other water bodies. In addition to their visual effect and their adverse impact in terms of the chemical oxygen demand, many synthetic dyes are toxic, mutagenic and carcinogenic [11].

The dye fixation on the fibers during the dyeing process is not total, leading to the dye release. The degree of fixation depends on dye/fiber combinations and on the special characteristics of the dyeing process. The treatment of textile effluents is particularly important in 
the case of intensely colored wastewaters containing reactive dyes, since these dyes are those with a lower degree of fixation to the fiber, they are less receptive to conventional treatments of effluents, such as adsorption and aerobic biodegradation and, finally, belong to the most used class, as they are used for dyeing cotton which is also the substrate that requires more water in its processing [12].

\section{Standards for textile effluent}

In the last few years, environmental legislature about the appearance of color in discharges (Table 2), combined with the increasing cost of water in the industrial sector has made the treatment and re-use of dying effluents increasingly attractive to the industry [13]. Government legislation is increasingly becoming more stringent regarding the removal of dyes from industrial effluents, especially in the more developed countries. Textile effluent discharge has to meet the following guidelines: coloration, toxicity, Total Organic Carbon (TOC) content, absorbable of organic halogens, the presence of metals and salt content [14].

Table 2. Standard and allowed for aqueous effluent discharge

\begin{tabular}{ll}
\hline Parameters & Standard/Allowed \\
\hline Temperature & Below $42^{\circ} \mathrm{C}$ at point of discharge \\
$\mathrm{pH}$ & Between $6-9$ at the point of discharge \\
$\mathrm{BOD}$ & $30 \mathrm{mg} / \mathrm{l}$ to surface water \\
$\mathrm{COD}$ & $50 \mathrm{mg} / \mathrm{l}$ to surface water \\
Suspended solids & $20 \mathrm{mg} / \mathrm{l}$ to surface water \\
Color & Below $1 \mathrm{ppm}$ \\
Toxic substances & Restricted by legislation \\
Volume and flow & Basis for the charging consented \\
\hline
\end{tabular}

The municipalities calculate effluent charges based on the organic load of the effluent (usually determined by COD), and therefore the discharge of desizing and scouring effluents usually results in extremely high effluent treatment penalties. Therefore, there is the need to develop cheap cost effective methods for the removal of these contaminants before discharge into the environment.

Dye removal techniques

The removal of the coloring matter from effluent is a major problem faced by industries. In general, the chemical structure of dyes contains conjugated double bonds and aromatic rings. Many synthetic dyes tend to persist in the environment due to the inherent stability of their molecular structure. Azo dyes for example have a characteristic azo linkage. The presence of this linkage decreases the susceptibility of azo dyes to oxidative reactions thus making them resistant to conventional degradation methods [15].

Currently, there are several methods that can be used in the removal of dyes from textile industrial effluents. However, due to the variety of existent dyes and to the effluents complexity, not all methods have the same efficiency and the combination of various methods may be required, since each method has its limitations. Existing methods can be divided into three categories: physical, chemical and biological.

\section{Physico-chemical methods}

The conventional methods used in the textile industry for the color removal from effluents include physico-chemical methods like coagulation/flocculation and activated carbon adsorption. Both flocculation and adsorption generate large amounts of toxic sludge and waste, which require a separate treatment before disposal [16]. However, this method always has high costs associated due to the reagents involved. Among the physical methods, adsorption and ion exchange have been most studied, being effective methods for dyes removal and the production of the high quality water [17]. However, the most commonly used adsorbents such as activated carbon involve high costs, turning adsorption a less attractive process.

Coagulation/flocculation method is also widely used in the color removal from textile effluents. Since large amounts of inorganic coagulants, such as iron and aluminium salts are required to obtain good removals, causing the formation of large amounts of toxic sludge, organic coagulants leading to relatively low production of sludge have been developed [18]. However, this method always has high costs associated due to the reagents involved.

The ultrafiltration and microfiltration are useful to separate the dyes from larger molecules present in the effluents, since membranes have larger pores. However, these processes have a disadvantage of high costs of installation, maintenance and the replacement of membranes [19].

Widely used techniques include oxidation reactions, photochemical oxidations and electrochemical treatment [3], out of which the oxidation processes are the most common. This is primarily due to its simplicity of application with hydrogen peroxide being the main oxidizing agent. Chemical oxidation removes the dye from the dye-containing effluent by oxidation resulting in aromatic cleavage of the molecules [20].

An effective means of decolorization of the dye containing effluent is the application of Advanced Oxidation Processes (Fenton and Fenton-like oxidation, ozonation, photochemical oxidation, electrochemical oxidation, photolysis, radiolysis, wet oxidation and the use of electronic beams or $y$-beams [21]. These processes are based on the generation of highly reactive species like hydroxyl radicals that have a strong oxidative potential $\left(E^{0}=+2.8 \mathrm{~V}\right)$. Ozonation is a method used to treat dyes in effluent. Although it decolorizes dyes effectively, it does not reduce COD adequately. It may produce exhausted ozone in the wastewater and increase the cost 
of the treatment. The conventional treatment processes have several shortcomings such as being unsuitable for use when the effluent contains high concentrations of the target pollutants, high running cost and low efficiency of the removal [22].

\section{Biological methods}

The use of biological methods to remove color from textile effluents is usually a cheaper alternative, since it presents no major processing costs. However, this method presents some disadvantages, since several dyes are designed to resist to microbial attack. Biological methods involve the use of bacteria, fungi and algae. Bacterial degradation has been mainly applied in the removal of azo dyes. However, this biological method has been found ineffective in removing color from several dyes. The azo dyes generally resist to aerobic degradation. However, its degradation was observed in anaerobic conditions, but aromatic amines are formed as the final product, which despite having no color can be toxic, mutagenic or carcinogenic [23]. Fungi can degrade textile dye effluents through their own action or by enzymes digestion produced by them. Ligninolytic fungi are most common in the treatment processes for textile dyes, although some non-ligninolytic are also effective [24]. Some algae are known to be used in effective decolorization of dyes from textile wastewaters [25].

\section{Enzymes in wastewater treatment}

Industrial waste effluents contain a variable mixture of both organic and inorganic substances though the actual nature and concentrations will depend on the source. Much of the organic matter is contained within fatty acids, carbohydrates and proteins. The inorganics contain predominantly heavy metals, brine salts, sulphites and sulphides. Though microorganisms can express enzymes that can degrade the most recalcitrant pollutants, they are wrought with problems. Moreover, bacteria exercise a very slow rate of degradation of polluted sites limiting their overall practical use for this purpose. Consequently, enzymology may be regarded as a key stone in the context of environmental biotechnology and biological remediation whether they are aerobic or anaerobic processes.

Commercial dyes are classified as azo, anthraquinone, phthalocyanine, triphenylmethane and heterocyclic with azo dyes, characterized by the functional azo group $(-\mathrm{N}=\mathrm{N}-)$, representing one of the largest class used in the printing and textile processing industries. These dyes and their degradative aromatic amine products are toxic and mutagenic to living systems and consequently are undesirable if released into the environment [26]. Enzymes from both anaerobic and aerobic systems have been reported to be effective in decolonization of the dyes with the majority of the results forthcoming from white rot fungi Phanaerochaete and Trametes. These organisms secrete laccases and manganese/lignin peroxidases that are capable of oxidative free radical cleavage of the azo bond. Due to the variability in the industrial effluent composition, as well as the structural diversity of the dye itself, the biodegradation of dyes found in the textile and/or printing sectors are more recalcitrant.

Enzymes have a number of features that make them more viable in relation to conventional catalysts: they are biodegradable catalysts, allow the operation at low and high substrate concentrations, allow the operation over a wide range of $\mathrm{pH}$, temperature and salinity, have a reduced sludge formation and are simple and easy to control [27]. All these advantages added to their high specificities and catalytic activities, with the possibility of designing enzymes with the exactly desired properties through genetic engineering and computational design, suggest the potential application of this process in the treatment of effluents.

The ligninolytic enzymes like lignin peroxidase, manganese peroxidase and laccase are produced by whiterot-fungi, normally when the levels of nutrients such as carbon, nitrogen or sulfur become limiting [28]. They are able to oxidize a large number of different compounds, and therefore they have been intensively studied in the textile wastewater treatment.

The production of lignin modifying enzymes by whiterot fungi has shown great potential in degrading azo dyes and related effluents. The main lignin modifying enzymes include two types of peroxidases lignin and manganese and a phenol oxidase, also called laccase. The research over the years has shown that the expression of lignin modifying enzymes varies according to taxonomy and culturing conditions [29]. Lignin peroxidase degrades azo dyes by oxidation of the phenolic group to produce a radical at the carbon bearing the azo linkage. The phenolic carbon is then attacked by a water molecule resulting in its break down to produce phenyldiazene which is easily oxidized by a one-electron reaction to generate nitrogen [30]. Manganese peroxidase has generated a lot of interest in enzyme biotechnology because of its high degradative potential. It is a specific enzyme that oxidizes $\mathrm{Mn}^{2+}$ to $\mathrm{Mn}^{3+}$ ions which are highly reactive [31]. The resultant products consist of low molecular mass fragments, quinones, ring-fission products, organic acids and carbon dioxide, all of which can serve as substrates for other reactions [31). Laccase enzymes have broad substrate specificity. The mechanism of laccase involves the removal of an $\mathrm{H}^{+}$atom from hydroxyl and amino groups of the ortho- and para- substituted mono and polyphenolic substrates, and aromatic amines. As a result, laccases have found the application in the treatment of a wide range of industrial effluents such as textile, paper and pulp, tannery and other industrial effluent containing chloro-lignins or phenolic compounds. The application of laccases to such processes requires the development of efficient production systems [32].

\section{Conclusion}

Effluent generated by the industries is one of the sources of pollution. Since the textile industries are one 
of the major water consumers, the problem faced by the textile industries is the effluent and waste disposal. Also, red listed chemicals and banned dyes are carcinogenic and highly toxic. These chemicals are not only poisonous to humans but are also found toxic to aquatic life and they may result in food contamination. Wastewater containing dyes is very difficult to treat, since the dyes are recalcitrant organic molecules, resistant to aerobic digestion and are stable to light. A synthetic dye in wastewater cannot be efficiently decolorized by traditional methods.

The technologies for the color removal can be divided into three categories: biological, chemical and physical. All of them have advantages and drawbacks. A biological treatment is often the most economical alternative when compared with other physical and chemical processes. Biodegradation methods such as fungal decolorization, microbial degradation, adsorption by microbial biomass and bioremediation systems are commonly applied to the treatment of industrial effluents because many microorganisms such as bacteria, yeasts, algae and fungi are able to accumulate and degrade different pollutants.

The use of various enzymes is in the early stages of the development, but their innovative applications are increasing and spreading rapidly into all areas of textile processing. The textile industry can greatly benefit from the expanded use of these enzymes as non-toxic, environmentally friendly compounds. In the wastewater treatment, enzymes can be utilized to develop remediation processes that are environmentally less aggressive than conventional techniques. Their versatility and efficiency even in mild reaction conditions gives them the advantage over the conventional physico-chemical treatment methods. The biological origin of enzymes reduces their adverse impact on the environment thereby making the enzymatic wastewater treatment an ecologically sustainable technique.

Despite the advantages of the enzymatic wastewater treatment, the major limitation in the use of enzymes is their prohibitive cost.

\section{References}

[1] B. Manu, S. Chaudhari, Anaerobic decolorization of simulated textile wastewater containing azo dyes, Bioresource Technology, 82 (2002) 225-231.

[2] T. Robinson, G. McMullan, R. Marchant, P. Nigam, Remediation of dye in textile effluent: A critical review on current treatment technologies with proposedalternative, Bioresource Technolology,77 (2001) 247-255.

[3] C.B. Shaw, C.M. Carliell, A.D. Wheatley, Anaerobic/ aerobic treatment of colored textile effluents using sequencing batch reactors, Water Research, 36 (2002) 1993-2001.

[4] K. Hunger, Industrial Dyes: Chemistry, Properties, Applications. First Edition, Wiley-VCH Verlag GmbH \& Co. KGaA, Weinheim, Germany, 2003, p. 685.

[5] D. Nuran, E. Esposito, Potential applications of oxidative enzymes and phenoloxidase-like compounds in wastewater and soil treatment: A review, Appl. Catalysis B: Environmental, 28 (2000) 83-99.
[6] P.M. Braile, J.E.W.A. Cavalcanti, Manual de tratamento de águas residuárias industriais, CETESB, São Paulo, Brasil, 1993, p. 764.

[7] I.M. Gonçalves, M.I. Ferra, M.T.P. Amorim, Processos de remoção biológica de corantes nos efluentes de indústria têxtil. Tecnologias do Ambiente, 11 (1996) 35-38.

[8] T. Santhi, S. Manonmani, T. Smitha, Kinetics and isotherm studies on cationic dyes adsorption onto Annona Squmosa seed activated carbon, International Journal of Engineering Science and Technology, 2 (2010) 287-295.

[9] E.R. Trotman, Dyeing and Chemical Technology of Textile Fibers. Sixth Edition. Edward Arnold, A Division of Hodder \& Stoughton, London, 1990, p. 690.

[10] A.B. dos Santos, F.J. Cervantes, R.E. Yaya-Beas, J.B. van Lier, Effect of redox mediator, AQDS, on the decolorization of a reactive azo dye containing triazine group in a thermophilic anaerobic EGSB reactor, Enzyme and Microbial Technology, 33 (2003) 942-951.

[11] K. Golka, S. Kopps, Z.W. Myslak, Carcinogenicity of azo colorants: influence of solubility and bioavailability, Toxicology Letters, 151 (2004) 203-210.

[12] C. O'Neill, F.R. Hawkes, D.L. Hawkes, N.D. Lourenco, H.M. Pinheiro, W. Delee, Color in textile effluents sources, measurement, discharge consents and simulation: a review, Journal of Chemical Technology and Biotechnology, 74 (1999) 1009-1018.

[13] J. Maier, A. Kandelbauer, A. Erlacher, A. Cavaco-Paulo, G.M. Gubitz, A new alkali-thermo-stable azoreductase from Bacillus sp. Strain SF. Applied and Environmental Microbiology,70 (2004) 837-844.

[14] T. Robinson, G. McMullan, R. Marchant, P. Nigam, Remediation of dye in textile effluent: A critical review on current treatment technologies with proposed alternative. Bioresource Technology, 77 (2001) 247-255.

[15] V.L. Maddhinni, H.B. Vurimindi, A. Yerramilli, Degradation of Azo Dye with Horseradish Peroxidase (HRP), Journal of the Indian Institute of Science, 86 (2006) 507-514.

[16] M.R. da Silva, L.R. de Sá, C. Russo, E. Scio, V.S. FerreriaLietão, The use of HRP in Decolorization of Reactive Dyes and Toxicological Evaluation of their Products, Enzyme Resources, (Published Online) Article ID 703824, (2010) 1-7.

[17] K.K.H. Choy, G. McKay, J.F. Porter, Sorption of acid dyes from effluents using activated carbon, Resources, Conservation and Recycling, 27 (1999) 57-71.

[18] A.I. Zouboulis, C. Xiao-Li, I.A. Katsoyiannis, The application of bioflocculant for the removal of humic acids from stabilized landfill leachates. Journal of Environmental Management, 70 (2004) 35-41.

[19] P.C. Vandevivere, R. Bianchi, W. Verstraete, Treatment and reuse of wastewater from the textile wet-processing industry: Review of emerging technologies, Journal of Chemical Technology and Biotechnology, 72 (1998) 289302.

[20] C. Raghavacharya, Color removal from industrial effluents - A comparative review of available technologies, Chemical Engineering World, 32 (1997) 53-64.

[21] S.A. Abo-Farah, Comparative Study of Oxidation of Some Azo Dyes by Different Advanced Oxidation Processes, Fenton, Fenton-Like, Photo-Fenton and Photo-FentonLike, American Journal of Science, 6 (2010), 128-142.

[22] M. Stanisavljević, L. Nedić, Removal of Phenol from Industrial Wastewaters by Horseradish (Cochlearia armoracia L.), Working and Living Environmental 
Protection, 2 (2004), 345-349.

[23] M. Isik, D.T. Sponza, Fate and toxicity of azo dye metabolites under batch long-term anaerobic incubations, Enzyme and Microbial Technology, 40 (2007) 934-939.

[24] M.A.E.-R. Wafaa, M. Hassan, M. Khalafallah, Microflora involved in textile dye waste removal, Journal of Basic Microbiology, 43 (2003) 167-174.

[25] H.H. Omar, Algal Decolorization and Degradation of Monoazo and Diazo Dyes, Pakistan Journal of Biological Sciences, 11 (2008) 1310-1316.

[26] D. Brown, B. Hamburger, The degradation of dyestuffs, Part 111 - investigations of their ultimate degradability, Chemosphere, 16(1987) 1539-1553.

[27] J.A. Nicell, J.K. Bewtra, N. Biswas, C. St. Pierre, K.E. Taylor, Enzyme catalysed polymerization and precipitation of aromatic compounds from aqueous solution, Canadian Journal of Civil Engineering, 20 (1993) 725-735.

[28] D.P. Barr, S.D. Aust, Mechanisms white rot fungi use to degrade pollutants, Environmental Science \& Technology, 28 (1994) 78-87.
[29] D. Wesenberg, I. Kyriakides, S.N. Agathos, White Rot Fungi and their enzymes for the treatment of industrial dye effluents, Biotechnology Advances, 22 (2003) 161 $-187$.

[30] E. Rodriguez, M.A. Pickard, R.V. Duhalt, Industrial dye decolorization by laccases from lignolytic fungi, Current Microbiology, 38 (1999) $27-32$.

[31] D. Ziegenhagen, M. Hofrichter, A simple and rapid method to gain high amounts of manganese peroxidase with immobilized mycelium of the agric white-rot fungus Clitocybula dusenii, Applied Microbiology Biotechnology, 53 (2000) $553-557$.

[32] S. Kahramann, O. Yasilada, Industrial and agricultural wastes for laccase production by White Rot fungi, Folia Microbiology, 46 (2001) 133 - 136.

\section{Izvod}

\section{PRIMENA ENZIMA ZA UKLANJANJE BOJE IZ OTPADNIH VODA TEKSTILNE INDUSTRIJE}

Kiro D. Mojsov ${ }^{1}$, Darko Andronikov ${ }^{1}$, Aco Janevski $^{1}$, Aco Kuzelov², Stevan Gaber ${ }^{3}$

(STRUČNI RAD)

UDK 628.31:677:577.15

${ }^{1}$ Tehnološko-tehnički fakultet, Univerzitet “Goce Delčev” Štip, Republika Makedonija

2 Poljoprivredni fakultet, Univerzitet “Goce Delčev" Štip, Republika Makedonija

3 Ekonomski fakultet, Univerzitet “Goce Delčev” Štip, Republika Makedonija

Smanjenje vodnih resursa je globalni problem. Efikasni tretman efluenata je važan korak ka očuvanju naših vodnih resursa. Neki zagađivači, kao što su boje, otporni su i ne razgrađuju se prilikom tretmana konvencionalnim metodama, tako da ostaju u životnoj sredini. Otpadne boje predstavljaju jednu od najproblematičnijih grupa zagađivača, jer se vizuelno lako identifikuju i nisu lako biorazgradive. Upotreba biotehnoloških procesa u tretmanu obojenih otpadnih voda tekstilne industrije privuklo je značajnu pažnju i poslednjih nekoliko godina su postignuti značajni rezultati. Ovaj rad opisuje primenu enzima kao alternativni metod za tretman takvih zagađivača. Od procesa za tretman otpadnih boja primenjuju se biološki tretman, filtracija, katalitičke oksidacije, sorpcija i kombinovani tretmani. Ovo naglašava potrebu da se sadašnje i buduće istraživanje fokusira na razvoj ekonomski isplativih i ekološki opravdanih metoda za prečišćavanje otpadnih voda.
Ključne reči: enzimi, otpadne boje, tekstilni efluent, metode obrade 